in considerable numbers, but the weather was unsuitable for the larvæ to produce many autumn specimens. V.atalanta and Colia croceus were scarce, but striking immigrations of Pieris rapce and $P$. brassicce from all parts caused great damage to greens. Generic names in full have now been added to the index table and nomenclature is brought up to date. The promptness of the appearance of the report under the difficulties of present conditions is most encouraging to all the voluntary workers concerned.

\section{Australian Aboriginal Artist}

ILLUSTRATIONs accompanying the printed report now available of a communication presented at the Canberra meeting of the Australian and New Zealand Association for the Advancement of Science which dealt with aboriginal sculpture render possible an independent judgment on material the discovery of which is hailed by the author, E. P. Goddard, as "one of the most noteworthy finds in many years" (Report. 24th Meeting Aust. and N. Zealand Assoc. Adv. Sci. 1939, Sect. F., Anthropology). The sculpture is the work of a woman of about thirty-two years of age, Kalboori Youngi by name, and a member of the Pitta-Pitta tribe. She is obviously a sculptor of natural genius, producing carved human figures remarkable both for their modelling and their detail, as well as their feeling for the disposal of mass and line. She works in two kinds of clays, of which one is used in the composition of the 'widow's caps' used in mourning rites. Her tool at first was a fine flake of quartzite, but she now employs a pocketknife which has been given to her.

Although the Pitta-Pitta are now in contact with station-life, Youngi has not come under mission influence, nor has she seen sculpture of any kind. The Pitta-Pitta tribe is described as "virtually a tribe of hereditary artists", apparently on the ground that that part of the Diamantina of central western Queensland, more especially Brighton Downs station, contains numerous rock-drawings, paintings and carvings in caves and on rocks "executed long before the white man took up his pastoral holdings". The familiarity with graphic art may suggest the orientation of the aboriginal sculptor in seeking a form of self-expression, unusual and unexpected though it may be, but the derivation of the medium of expression, the sculptor's art, still seems obscure. The sculptures consist of human figures, male and female, singly and in groups, with horses and dogs as accessories rather than main elements in the composition in a manner which suggests the technique of European portraiture. The author compares this work with early Mesopotamian and Egyptian, but the comparison which suggests itself is with Sumerian, and notably the statue of Gudea.

\section{Electrical Development in Ireland}

Following the reading by Mr. P. G. Murphy of a paper on "The Electricity System of Eire" at a meeting of the University College (Dublin) Engineering Society, Mr. Sean McEntee, Minister for Industry and Commerce, said that he agreed with the author's estimate that in normal circumstances the demand for electricity in Eire might be expected to double itself within a decade, so that the country would then be using about 800 million of electric units yearly. By interconnecting the electricity systems of Eire and Northern Ireland this was quite feasible. It did not necessarily follow that in normal circumstances the exchange of normal power would be very large, but the interconnexion would undoubtedly help to reduce the amount of stand-by plant to meet emergencies, and would enable provision to be made for security of supply at a far lower cost than could be made by either system independently. Perhaps this development may be hastened by the present abnormal situation.

From the experience of the Electricity Supply Board, a combination of water-driven stations and fuel-burning stations is essential in Eire. The Shannon scheme has reduced the dependence of Eire upon foreign fuel to about 220,000 tons of coal yearly. On the other hand, the Electricity Supply Board's accounts still shows that during the year ended March 31, 1939, £95,000 was spent on fuel, most of which was imported. Next to the Shannon and the Liffey, the Erne and the Boyne appear to be the most important rivers from a hydro-electric point of view. The Boyne might produce an additional 100 million kwh. per annum, but its development might be very unsatisfactory owing to high rates of compensation to landowners. The Erne, if satisfactorily developed, might give an annual output of 200 million kwh., but its storage facilities and a large part of its eatchment area lie within the six counties of the north-a fact which has created a very difficult problem in drainage for the Government of Northern Ireland. Mr. McEntee believes it possible to develop the hydro-electric potentialities in such a way as to improve considerably the drainage in the area affected, but any such proposals would require the active co-operation of Northern Ireland and Eire.

\section{Roads with a Cotton Fabric Basis}

Is the United States of America there is a widespread interest at present in the new 'cotton roads' which are being made across the continent from New York to California and from Florida to Maine. According to an article published in Roads and Road Construction of April 1, the modern procedure in construction is to lay the cotton fabric on a surface treated with bituminous material. The bituminous material is then applied to the fabric and completely covered with crushed mineral aggregate. The crushed cover material is rolled in and a lighter application of bituminous material is applied and covered with a layer of chips, which are rolled in with a heavy roller. The best results in cotton roads have been obtained from cloth of comparatively open weave. The breaking strength varies between 25 and $45 \mathrm{lb}$. (grab method) according to grade. The most practicable fabrics cost between 450 and 750 dollars a mile for a road $18 \mathrm{ft}$. wide. 
In New Jersey, cotton fabric and tar were applied on 600 linear $\mathrm{ft}$. of a gravel road in South Brunswick township. After a year of service an inspection was made. Due to snow and light rain for two days the road and adjoining ground was saturated. On the part of the road where the fabric had not been used, the surface was broken in twelve places. Brokén areas were $0 \cdot 5-1 \cdot 5 \mathrm{sq}$. $\mathrm{ft}$. in area and were quite soft. In other places the surface was resilient and water would ooze to the surface under pressure with a blunt instrument. On the other hand, there were no broken places in the section which had been treated with cotton fabric, and the surface was tougher and less easily punctured with a screwdriver. Recent reports sent in from a number of highway departments indicate that short test sections of bituminoussurfaced roads, having cotton as part of their construction, have decreased maintenance costs and require less patching. The South Carolina Highway Department has used cotton fabric on bridge surfaces also with a marked degree of improvement in maintaining a satisfactory bituminous surface.

\section{Progress in Stereo Plate Casting}

A PAPER on stereo plate casting published in the Electrical Review of March 8 gives a survey of the progress made in the application of electric heating to autoplate machines for the production of stereo plates for rotary printing presses. For several years past much has been done in the United States, and pioneer work in England took place so long ago as 1930 at the Daily Mail offices in Manchester, where four electrically heated autoplate machines loaded at 120 kilowatts each represented, it is claimed, the first electric printing works foundry in Europe. The next major move was not until about a year ago, when Allied Newspapers Ltd. decided to electrify completely the autoplate installation at their Manchester offices.

The electric autoplates are fitted with baths each having a capacity of about $7 \frac{1}{2}$ tons of stereo metal, which, when casting is in progress, is kept molten at about $650^{\circ} \mathrm{F}$. and at about $450^{\circ} \mathrm{F}$. during stand-by periods. It takes about two minutes to raise the temperature from $450^{\circ}$ to $650^{\circ} \mathrm{F}$. The special immersion heaters are of grid construction, and in the largest machines have an installed heating load of $264 \mathrm{kw}$. This is probably the first time that metalsheathed tubular heaters have been directly immersed in cast metal, and the result has been most efficient operation. Since the completion of the Allied Newspapers installation, electric heating has also been introduced at the foundries in Manchester of Odhams Press, Ltd., and the Manchester Guardian. In the later units there is automatic temperature control.

\section{Carnegie Trust for Scottish Universities}

THE latest report of the Carnegie Trust for the Universities of Scotland shows the varied and substantial aid given. The grants are arranged in quinquennial distributions, the seventh of which covers the years 1935-1940. An aggregate of $£ 257,300$ was allocated to the universities and extra-mural institutions. The Trust is generally associated with libraries and students' fees, but it also does a good deal for specialists engaged in scientific research, and it is satisfactory to read the good reports of their work, which is as wide as in former years, and maintains an excellent standard. Several of the fellows and scholars have secured places which render them independent of the Trust. The subjects studied range from the Atlantic grey seal in the Western Islands to protein metabolism and a new synthesis of compounds of therapeutic value. The Trust subscribes to the production of good books not likely to have a popular sale and to such enterprises as a further study of the Roman occupation of southern Scotland, aided by spotting from the air.

We notice in detail that in the Glasgow, Edinburgh, and Aberdeen centres agricultural colleges have received $£ 200$ a year each. St. Andrews has had $£ 33,150$ for alterations and extensions in the five years, and Glasgow, towards the cost of the new Chemistry Institute, $£ 59,000$. The Edinburgh accounts include $£ 13,000$ for a lecturer in English, also large sums for the endowment of prehistoric archæology and ethnology, while the Men's and Women's Unions are each put down for $£ 3,000$. Equipment for medical departments of the University comes to $£ 7,250$. Arrangements have been made to meet the difficulties caused by the War.

\section{Chemical Research in Australia}

THe Commonwealth Government has approved a further addition to the activities of the Council for Scientific and Industrial Research. A division of industrial chemistry is to be established with headquarters adjoining the recently erected Aeronautical Research Laboratory at Fisherman's Bend, Port Melbourne. $£ 50,000$ has been provided for the initial building and its equipment, and abundant space is available for later extensions. After prolonged discussions with leading industrialists, it has been decided to concentrate upon study of certain aspects of each of the following major lines: (1) nonmetallic minerals and their utilization; (2) metals and alloys, particularly from the point of view of corrosion; (3) leather, hides and fellmongery; (4) dairy products; with (5) a miscellaneous group where work will begin on paints and varnishes. Dr. I. W. Wark has been appointed to control the work of the division.

\section{Minerals of Canada}

A usEFux publication which has made its annual appearance is "The Canadian Mineral Industry in 1938" (Dept. of Mines and Resources, Mines and Geology Branch, No. 804. 25 cents). It gives the output of all important mines in Canada and the destination and use of the product. It is noteworthy that Canada, in its pitchblende deposit near the Great Bear Lake, shares with the Belgian Congo the source of nearly all the world's radium. The Canadian output has caused a considerable fall in the price of radium in recent years. 